Scientific paper

\title{
Determination of Candesartan in Human Plasma with Liquid Chromatography - Tandem Mass Spectrometry
}

\author{
Vanja Forjan, ${ }^{1, *}$ Lea Cvitkovič Maričič, ${ }^{1}$ Helena Prosen ${ }^{2}$ \\ and Darinka Brodnjak Vončina ${ }^{3}$ \\ ${ }^{1}$ Krka, d.d., Novo mesto, Šmarješka cesta 6, 8501 Novo mesto, Slovenia \\ ${ }^{2}$ University of Ljubljana, Faculty of Chemistry and Chemical Technology, Večna pot 113, 1000 Ljubljana, Slovenia \\ ${ }^{3}$ University of Maribor, Faculty of Chemistry and Chemical Engineering, Smetanova 17, 2000 Maribor, Slovenia \\ * Corresponding author: E-mail: vanja.forjan@ krka.biz \\ Tel.: +386-7-331-9444; Fax: +386-7-331-2558
}

Received: 23-07-2015

\begin{abstract}
A sensitive, specific and reproducible liquid chromatography-tandem mass spectrometry method was developed and validated for the determination of candesartan in human plasma. Candesartan was separated from endogenous components present in plasma by solid-phase extraction. Chromatographic separation was performed on a Gemini C18 analytical column using mobile phase acetonitrile $-5 \mathrm{mM}$ ammonium formate $(90: 10, v / v)$ at a flow rate of $0.3 \mathrm{~mL} / \mathrm{min}$. Liquid chromatography-tandem mass spectrometry with electrospray ionization in positive mode and selected reaction monitoring (SRM) was used for detection. The mass transitions $m / z 441.3>263.1$ and $445.5>267.1$ were used to determine candesartan with candesartan- $\mathrm{d}_{4}$ as an internal standard. The developed method was validated in the concentration range of $1-400 \mathrm{ng} / \mathrm{mL}$ in human plasma. The lower limit of quantification (LLOQ) was $1 \mathrm{ng} / \mathrm{mL}$. The method proved to be suitable for application in pharmacokinetic studies.
\end{abstract}

Keywords: Candesartan, liquid chromatography - tandem mass spectrometry, human plasma.

\section{Introduction}

Candesartan is an angiotensin II type one receptor (AT1) blocking agent given orally as the prodrug candesartan cilexetil which is rapidly and completely bioactivated by ester hydrolysis to candesartan after gastrointestinal absorption. Candesartan is indicated for the treatment of essential hypertension and in patients with heart failure and impaired ventricular systolic function. ${ }^{1}$

When developing ageneric medicine (pharmaceutical products), it is necessary to conduct a bioavailability study to demonstrate that the original medicine is interchangeable with the generic one. In these studies selected pharmacokinetic parameters of the two products are compared on the basis of the concentration profile of the active substance determined in biological samples.
Several analytical methods were reported for the quantification of candesartan in human plasma. ${ }^{2-9}$ Some of these methods were based on high-performance liquid chromatography (HPLC) with UV detection and fluorescence detection. ${ }^{2,3}$ Due to the increasing demands in pharmacokinetics studies, analytical methods must be specific, sensitive and rapid. These conditions are fully satisfied by LC-MS/MS. ${ }^{4-9}$ Some reported methods involve the preparation of plasma samples by liquid-liquid extraction $^{4,5}$ or solid-phase extraction ${ }^{3,6,7}$ or by precipitation of proteins. ${ }^{8,9}$ The protein precipitation technique, which is a fast and simple technique, that requires a small sample volume, no preconcentration is obtained and plasma supernatant can contain several matrix components. Recently, Singh and colleagues ${ }^{5}$ presented an LCMS/MS method that requires a small sample volume of $100 \mu \mathrm{L}$, however, the plasma preparation by liquid-liquid extrac- 
tion requires large quantities of toxic solvents and additional evaporation of the extract, which makes this method too time-consuming for the preparation of samples. With some of the methods ${ }^{6,8,9}$ a long retention time of candesartan is obtained, resulting in long analysis, which makes the studies with a large number of samples very time consuming.

The here presented method was developed for the determination of candesartan in human plasma. To be adequate for the intended purpose, the method has to be sensitive, accurate and precise, which was all confirmed by its validation according to the requirements proposed by Viswanathan et al. ${ }^{10}$ and OECD Principles of Good Laboratory Practice. ${ }^{11}$ Candesartan from human plasma was extracted by solid-phase extraction which is a very efficient technique for bioanalytical sample preparation. LCtandem mass spectrometry with electrospray ionization in positive mode and selected reaction monitoring (SRM) mode was used for the analysis.

This article proposes the use of isotopically labeled internal standard candesartan- $\mathrm{d}_{4}$ which has been proven to provide results with excellent precision and accuracy and which can be used with advantage for a reliable and accurate measurement of candesartan in human plasma.

\section{Experimental}

\section{1. Chemicals and Materials}

The reference standard of candesartan $(98.5 \%)$ was obtained from Krka, d.d., Novo mesto (Slovenia). Candesartan- $d_{4}(97.3 \%)$, which was used as the internal standard, was purchased from Synfine Research (Canada).

Methanol and water were obtained from Merck (Germany), acetonitrile and formic acid from J. T. Baker (The Netherlands) and ammonia solution and sodium hydroxide from Fluka (Germany). All organic solvents were of HPLC grade and chemicals and reagents were of analytical grade. Heparinized drug-free human plasma (including a batch of hemolytic and lipemic plasma) was supplied by Trina Bioreactives AG (Switzerland) and stored at $-20{ }^{\circ} \mathrm{C}$ until used.

The test formulation was the $32 \mathrm{mg}$ Candesartan tablet.

\section{2. Instrumentation}

RapidTrace SPE Workstation (Zymark, USA) was used for automated solid-phase extraction procedures (SPE).

Liquid chromatograph (LC) Agilent Technologies 1200 Series with an autosampler PAL HTC CTC Analytics hyphenated to tandem triple quadrupole mass spectrometer (MS/MS) MDS-Sciex API 4000 was used for the LC-MS/MS analysis. Peak area ratios of candesartan ver- sus the internal standard were processed by Analyst software version 1.4.2.

\section{3. LC-MS/MS Conditions}

Chromatographic separation was obtained on a Gemini C18 110Å column $(50 \mathrm{~mm} \times 2 \mathrm{~mm}$ internal diameter (ID), $5 \mu \mathrm{m}$; Phenomenex (USA) preceded by a guard column Gemini C18 110 (4 mm × 2 mm ID, $5 \mu \mathrm{m}$; Phenomenex) operating at $+20^{\circ} \mathrm{C}$. The autosampler temperature was kept at $+5{ }^{\circ} \mathrm{C}$. The mobile phase consisted of acetonitrile and $5 \mathrm{mM}$ ammonium formate $(90: 10, v / v)$. The flow rate was $0.3 \mathrm{~mL} / \mathrm{min}$. The total run time was $2 \mathrm{~min}$ and the retention time was $0.58 \mathrm{~min}$ for candesartan and internal standard. The injection volume was $10 \mu \mathrm{L}$.

Mass spectrometer was operated in the positive ionization mode. Optimization of MS/MS method was performed with the "Infusion Optimization" where a direct injection of $10 \mathrm{ng} / \mathrm{mL}$ solution of candesartan and internal standard was carried out while monitoring the characteristic mass transitions. The compound-specific parameters such as collision energy, declustering potential and collision exit potential were optimized. The SRM mode was used for detection and quantitation. The SRM transitions at $\mathrm{m} / \mathrm{z} 441.3>263.1$ for candesartan and $\mathrm{m} / \mathrm{z} 445.5>$ 267.1 for internal standard were used for the quantification of candesartan and internal standard, respectively. The mass spectra are presented in Figure 1. Quantitation was performed using weighted linear regression analysis (1/conc.) of peak area ratios of candesartan and internal standard.

\section{4. Standard Solutions, Calibration Curve (CC) and Quality Control (QC) Samples}

Candesartan and internal standard (candesartan$\mathrm{d}_{4}$ ) stock standard solutions at concentrations of 1 $\mathrm{mg} / \mathrm{mL}$ and $100 \mu \mathrm{g} / \mathrm{mL}$, respectively, were prepared in methanol. Working standard solutions for candesartan and internal standard were prepared from stock standard solution using methanol solution as diluent. All standard working solutions were kept at $+5{ }^{\circ} \mathrm{C}$. From them, we prepared samples for the calibration curve (CC) within the range of 1 to $400 \mathrm{ng} / \mathrm{mL}(1,2,5,10,25,50,100$, $200,300,400 \mathrm{ng} / \mathrm{mL}$ ) and for quality control (QC) samples at four candesartan concentration levels $(3,15,75$, $280 \mathrm{ng} / \mathrm{mL}$ ).

\section{5. Sample Preparation}

Strata X extraction cartridges, $60 \mathrm{mg} / 3 \mathrm{~mL}$, were obtained from Phenomenex (USA). A $500 \mu \mathrm{L}$ aliquot of human blank plasma sample was mixed with $100 \mu \mathrm{L}$ of internal standard solution $(500 \mathrm{ng} / \mathrm{mL}), 100 \mu \mathrm{L}$ of candesartan working standard solutions for calibration curve or quality control samples and $500 \mu \mathrm{L}$ of water. In sample 
a)

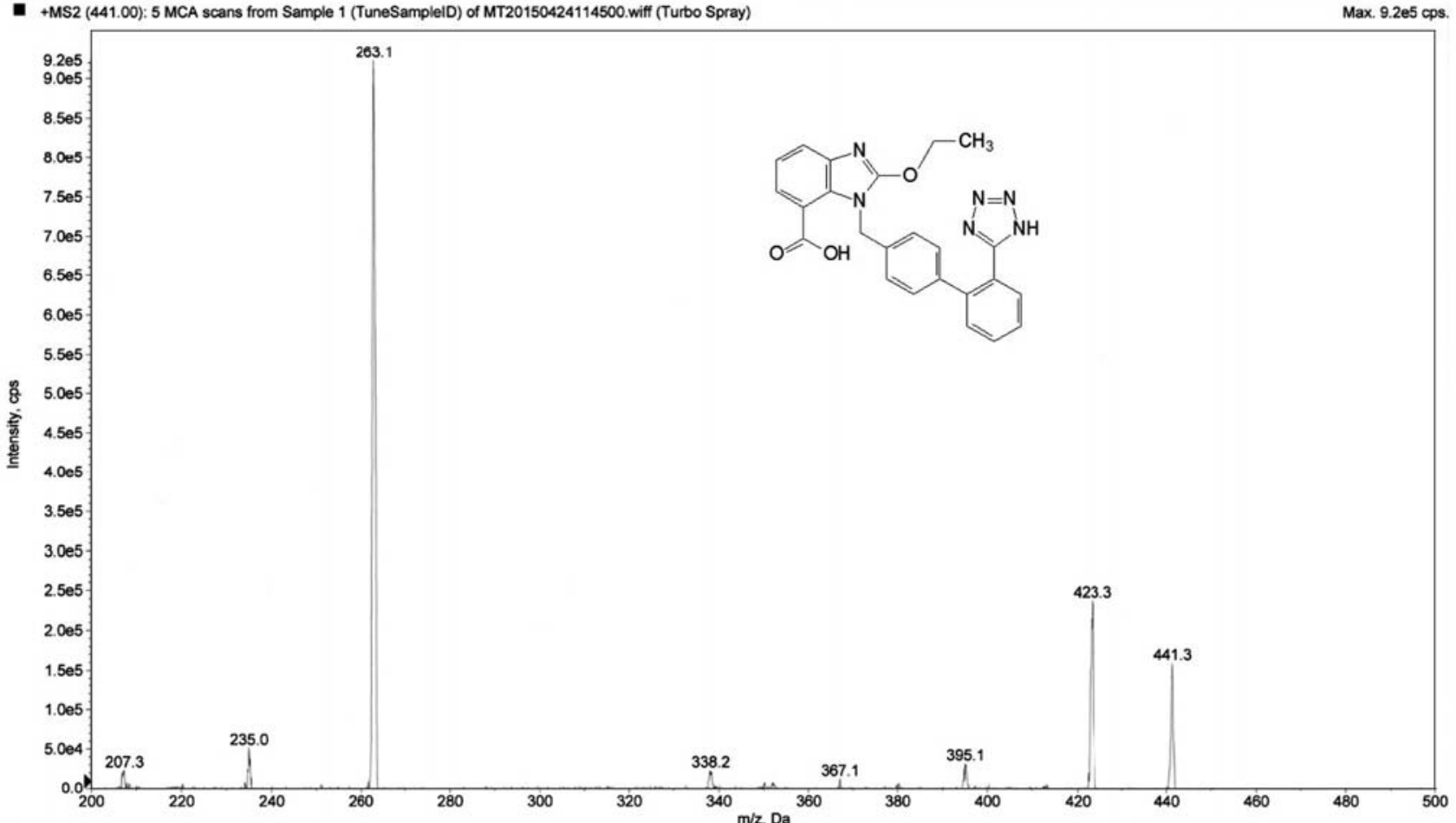

b)

- +MS2 (445.10): 5 MCA scans from Sample 1 (TuneSamplelD) of MT20150424114706. wiff (Turbo Spray)

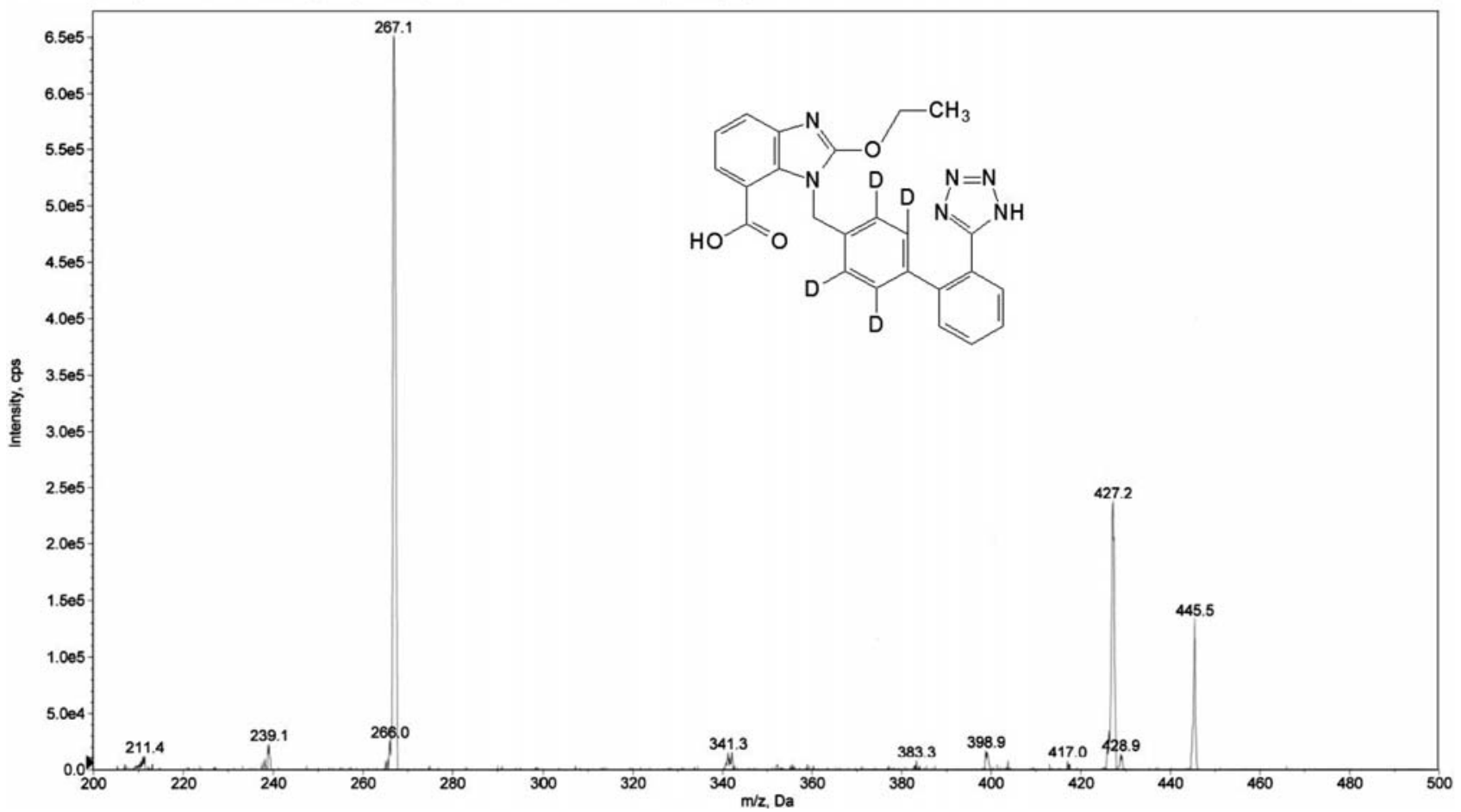

Figure 1: Product mass spectra (MS/MS) and chemical structure of (A) candesartan and (B) candesartan- $\mathrm{d}_{4}$.

preparation for study samples, the same procedure was followed, except for the addition of candesartan working standard, which was replaced by addition of $100 \mu \mathrm{L}$ of methanol. The prepared sample was loaded onto a Strata $\mathrm{X}$ extraction cartridge that had been first pre-conditioned with $2.0 \mathrm{~mL}$ of acetonitrile and then twice with $2.0 \mathrm{~mL}$ of 
water. After the washing with $2.0 \mathrm{~mL}$ of water, candesartan and internal standard were eluted with $1.5 \mathrm{~mL}$ of acetonitrile. All plasma samples, including the blank samples, samples for the calibration curve, quality control samples and the samples for validation were treated using the same sample preparation procedure. The extracts (10 $\mu \mathrm{L})$ were injected into the LC-MS/MS system.

\section{Results and Discussion}

The presented method was validated for specificity, lower limit of quantification, linearity, precision and accuracy, matrix effect, matrix factor, sample dilution, sample preparation recovery, hemolysis effect, solution stability, stability in plasma and carry-over test performance. All validation procedures were performed according to the acceptance criteria for bioanalytical method validation. ${ }^{10,11,12}$ All acceptance criteria are presented in Table 1.

\section{1. Specificity}

Specificity was demonstrated by using six independent sources of blank matrix, which were individually analyzed and evaluated for the presence of any interference. When the chromatograms of the plasma samples spiked with candesartan and internal standard (see supplementary material S1-S6) were compared with the chromatograms of the blank plasma samples, no significant interference was observed in the six blank matrix samples at the retention times and mass transitions of candesartan or internal standard.

Table 1: Acceptance criteria for validation parameters.

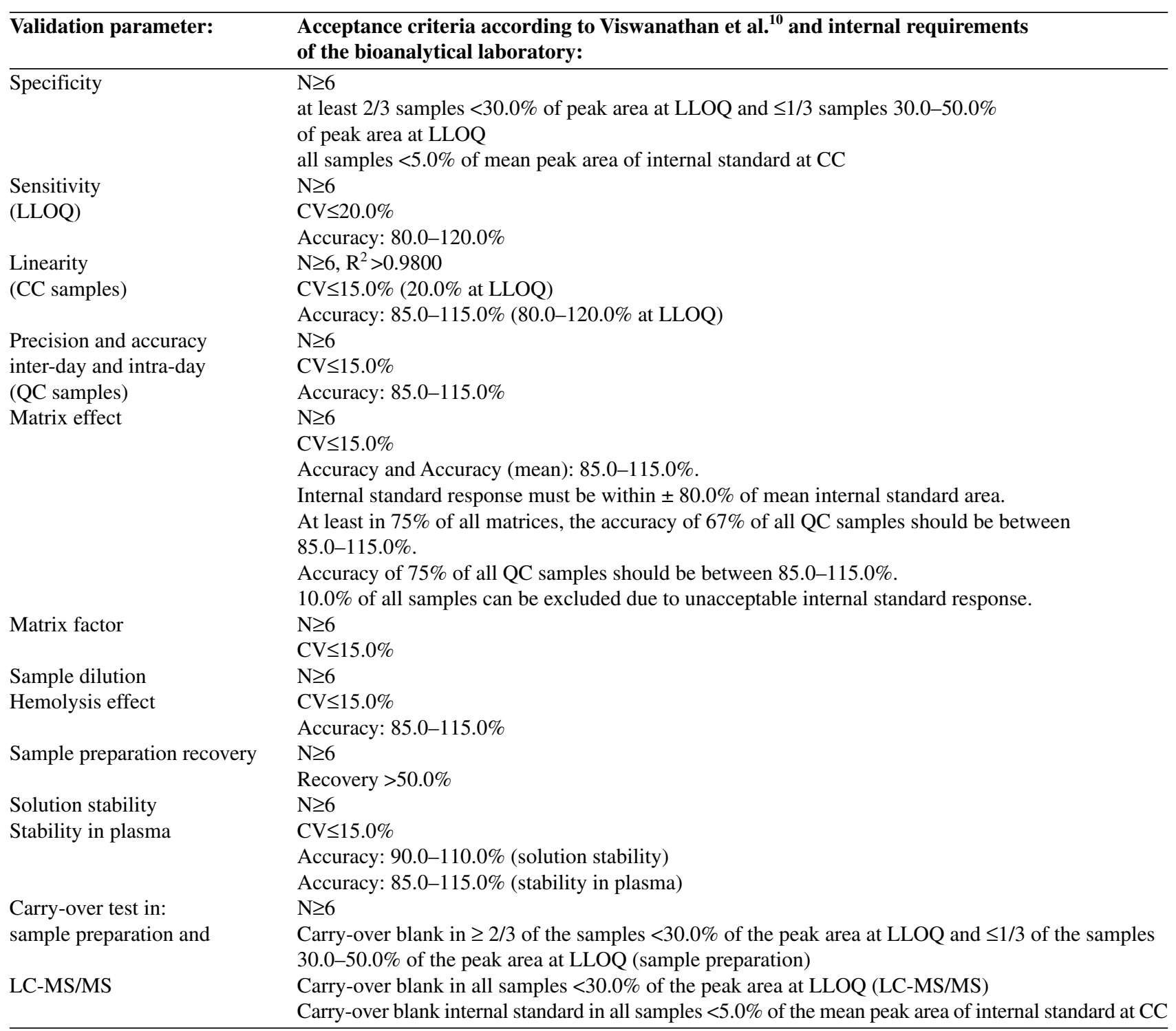




\section{2. Sensitivity (Lower Limit of Quantification)}

The lower limit of quantification (LLOQ) was determined by analysing plasma spiked with candesartan at the lowest calibration level $(1 \mathrm{ng} / \mathrm{mL})$ independent from the daily calibration curve. The precision (CV) and accuracy in the inter-day runs were within the criteria. The signal to noise ratio at LLOQ was at least 27.5. Figure 2 shows a
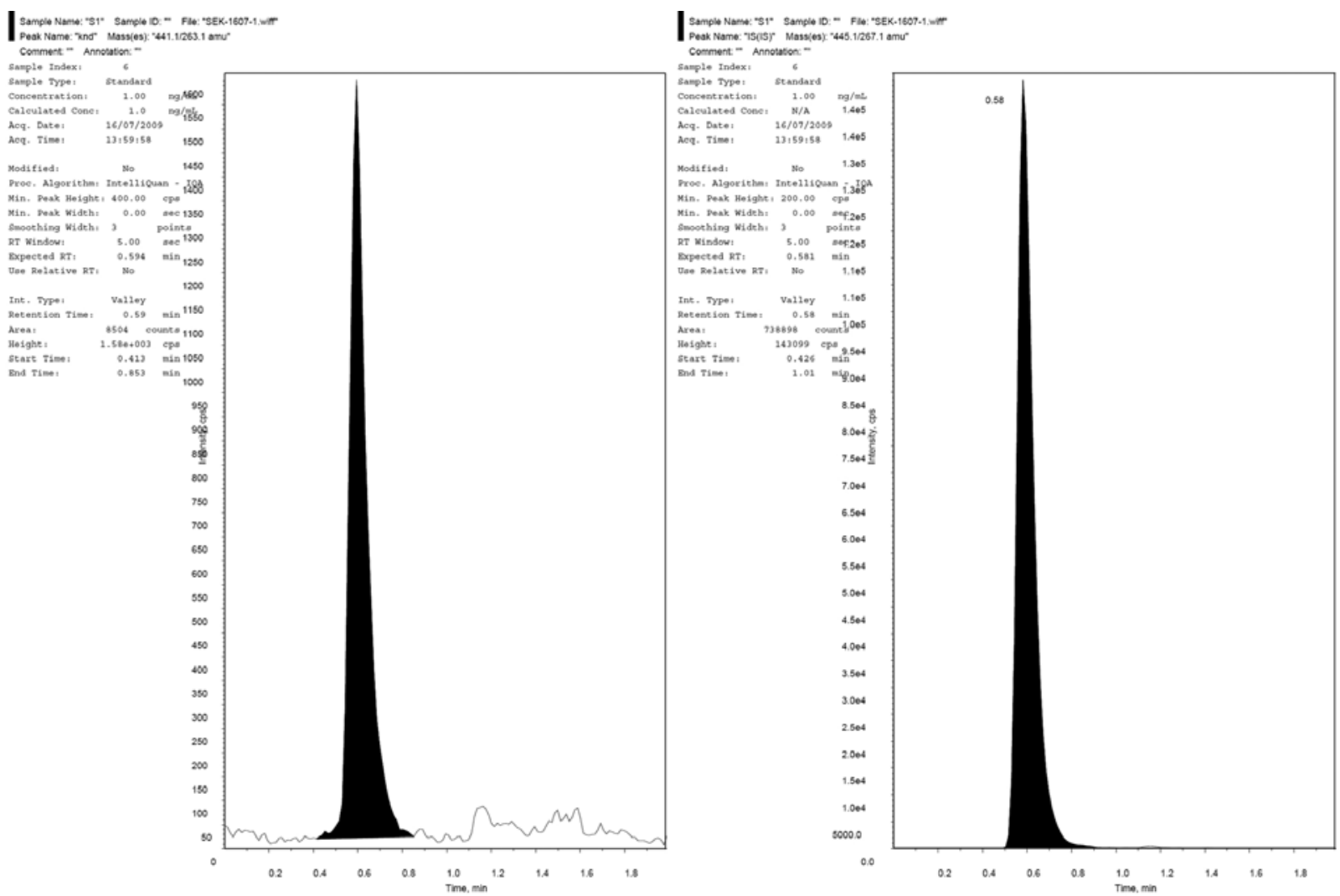

Figure 2: Representative SRM chromatogram of extracted LLOQ plasma sample containing candesartan (1 ng/mL, left) and internal standard (100 $\mathrm{ng} / \mathrm{mL}$, right).

Table 2: Precision and accuracy of calibration samples and calibration curve parameters of candesartan in human plasma for sample number 14.

\begin{tabular}{|c|c|c|c|c|c|c|c|c|c|c|c|c|c|}
\hline $\begin{array}{l}\text { Nominal } \\
\text { conc. } \\
(\mathrm{ng} / \mathrm{mL})\end{array}$ & \multicolumn{10}{|c|}{ Calculated concentration of candesartan $(\mathrm{ng} / \mathrm{mL})$} & $\begin{array}{c}\text { Slope } \\
\mathbf{k} \\
\end{array}$ & $\begin{array}{c}\text { Intercept } \\
\text { n } \\
\end{array}$ & $\begin{array}{c}\text { Correlation } \\
\text { coefficient } \\
\mathbf{r} \\
\end{array}$ \\
\hline run 1 & 1.0 & 1.9 & 5.0 & 9.9 & 25.0 & 50.7 & 100.8 & 207.4 & 293.7 & 397.5 & 0.0107 & 0.00113 & 0.9998 \\
\hline run 2 & 1.0 & 2.0 & 5.0 & 9.9 & 25.4 & 50.9 & 100.1 & 207.6 & 293.4 & 397.6 & 0.0107 & 0.00093 & 0.9998 \\
\hline run 3 & 1.0 & 1.9 & 4.9 & 10.2 & 25.3 & 50.3 & 99.5 & 201.1 & 304.2 & 394.6 & 0.0106 & 0.00122 & 0.9999 \\
\hline run 4 & 1.0 & 1.9 & 4.9 & 10.2 & 25.4 & 49.4 & 100.8 & 202.8 & 299.5 & 397.2 & 0.0106 & 0.00131 & 1.0000 \\
\hline run 5 & 1.0 & 2.0 & 5.0 & 9.8 & 25.4 & 50.9 & 100.6 & 202.1 & 286.6 & 409.5 & 0.0107 & 0.00117 & 0.9996 \\
\hline run 6 & 1.0 & 1.9 & 5.0 & 10.2 & 25.4 & 50.2 & 99.8 & 200.8 & 301.2 & 397.4 & 0.0106 & 0.00151 & 1.0000 \\
\hline run 7 & 0.9 & 2.2 & 5.0 & 9.8 & 25.1 & 50.4 & 100.6 & 203.4 & 290.2 & 405.4 & 0.0107 & 0.00064 & 0.1000 \\
\hline run 8 & 1.1 & 1.8 & 4.9 & 10.1 & 25.7 & 50.1 & 100.4 & 202.3 & 299.7 & 396.9 & 0.0106 & 0.00222 & 1.0000 \\
\hline run 9 & 1.1 & 1.9 & 4.9 & 9.7 & 24.2 & 49.7 & 101.9 & 202.8 & 290.5 & 406.4 & 0.0108 & 0.00188 & 0.9997 \\
\hline run 10 & 1.0 & 1.9 & 5.1 & 10.1 & 25.5 & 50.5 & 100.9 & 201.1 & 299.6 & 397.3 & 0.0106 & 0.00127 & 1.0000 \\
\hline run 11 & 1.0 & 2.1 & 5.0 & 9.9 & 25.3 & 49.4 & 99.9 & 193.5 & 310.2 & 396.8 & 0.0106 & 0.00036 & 0.9997 \\
\hline run 12 & 1.0 & 1.9 & 4.8 & 10.3 & 25.4 & 50.3 & 100.3 & 199.8 & 300.1 & 399.0 & 0.0106 & 0.00109 & 1.0000 \\
\hline run 13 & 0.9 & 2.0 & 5.0 & 10.1 & 25.8 & 48.8 & 105.2 & 203.5 & 303.7 & 388.0 & 0.0107 & 0.00214 & 0.9996 \\
\hline run 14 & 0.8 & 2.1 & 5.3 & 10.3 & 25.5 & 48.6 & 105.7 & 202.5 & 305.4 & 386.8 & 0.0106 & 0.00352 & 0.9995 \\
\hline Mean (14) & 0.99 & 1.96 & 4.99 & 10.04 & 25.31 & 50.01 & 101.2 & 202.2 & 298.4 & 397.9 & & & \\
\hline $\mathrm{CV}(\%)$ & 7.8 & 5.5 & 2.3 & 2.0 & 1.5 & 1.5 & 1.9 & 1.7 & 2.2 & 1.6 & & & \\
\hline Accuracy (\%) & 99.0 & 98.0 & 99.8 & 100.4 & 101.3 & 100.0 & 101.2 & 101.1 & 99.5 & 99.5 & & & \\
\hline
\end{tabular}


representative chromatogram of an extracted LLOQ plasma sample. The inter-day precision (CV) of the assay was $8.9 \%$ and the accuracy was $95.0 \%$.

\section{3. Linearity}

For validation of linearity in the range between 1 and $400 \mathrm{ng} / \mathrm{mL}$ blank human plasma was spiked with candesartan at ten concentration levels in seven different days. The calibration curves were constructed by linear regression analysis of the peak-area ratio vs. concentration of candesartan. A weighted linear regression curve (1/conc.) was found to best represent the detector response/concentration relationship for candesartan in human plasma. The calibration function was calculated using Analyst software 1.4.2. Back-calculated values of candesartan in calibration samples and summary of calibration curve parameters are presented in Table 2. The correlation coefficient for 14 repeats of the calibration curve varies between 0.9995 and 1.0000 , which shows an excellent linearity of the method.

\section{4. Precision and Accuracy}

Intra-day and inter-day precision and accuracy of the method were obtained by an analysis of the replicates of plasma QC samples at four concentration levels (3, 15, 75 and $280 \mathrm{ng} / \mathrm{mL}$ ). The precision of the method was expressed as the coefficient of variation $(\mathrm{CV})$ of the repeated assays and accuracy was given as the ratio between mean found and nominal concentrations. Table 3 shows a summary of the QC data obtained at four concentration levels of $\mathrm{QC}$ during fourteen validation runs.

Table 3: Intra-day and inter-day accuracy and precision of candesartan determination in human plasma.

\begin{tabular}{ccccc}
\hline $\begin{array}{c}\text { Nominal conc. } \\
(\mathbf{n g} / \mathbf{m L})\end{array}$ & \multicolumn{2}{c}{ Intra-day $(\boldsymbol{N}=\mathbf{8})$} & \multicolumn{2}{c}{ Inter-day $(\boldsymbol{N}=\mathbf{2 9})$} \\
$\mathbf{C V}$ & Accuracy & $\mathbf{C V}$ & Accuracy \\
\hline 3 & $\mathbf{( \% )}$ & $\mathbf{( \% )}$ & $\mathbf{( \% )}$ & $\mathbf{( \% )}$ \\
15 & 2.1 & 100.3 & 5.5 & 100.7 \\
75 & 0.6 & 101.1 & 1.7 & 99.9 \\
280 & 0.8 & 101.6 & 2.1 & 100.6 \\
\hline
\end{tabular}

\section{5. Matrix Effect}

Samples for the determination of the matrix effect were prepared at low quality control level ( $3 \mathrm{ng} / \mathrm{mL})$ using eight different sources of human plasma, including one hemolytic and one lipemic plasma sample. Three replicates of each matrix were analyzed in a single run and accuracy for each matrix was calculated. No matrix effect was found in 8 out of 8 different sources of the plasma tested.

\section{6. Matrix Factor}

For the matrix factor (MF), extracted blank human plasma samples from eight different human plasma sources (spiked at 3 and $280 \mathrm{ng} / \mathrm{mL}$ of candesartan and 100 $\mathrm{ng} / \mathrm{mL}$ of internal standard) were compared with solutions of candesartan and internal standard at the same concentration levels. The mean MF of candesartan was 1.251 and the mean MF for internal standard was 1.266. The internal standard-normalised MF was also calculated by dividing the MF of candesartan by the MF of the internal standard, and the value 0.988 was obtained $(\mathrm{CV}=$ $4.1 \%$ ). According to Viswanathan et al. ${ }^{10}$ an absolute matrix factor of about 1 is not necessary for a reliable bioanalytical assay. However, the variability of MF should be tested and fall below $15 \%$. In the present method, the variability in matrix factors is indirectly determined with $\mathrm{CV}$ evaluation of the matrix effect. The CV of 24 low concentration QC samples in 8 different sources of plasma is $10.5 \%$, which is less than $15 \%$, so the criterion from Viswanathan et al. ${ }^{10}$ is met.

\section{7. Sample Dilution}

Dilution of plasma samples was checked at the double value of high QC $(560 \mathrm{ng} / \mathrm{mL})$ concentration and five-fold value of $1400 \mathrm{ng} / \mathrm{mL}$ (a pool of sample was prepared by spiking drug-free plasma with candesartan Eight replicates with the dilution factor 2 and eight replicates with the dilution factor 5 were analyzed. No significant deviation in accuracy of candesartan concentration by sample dilution was observed. The dilution accuracy was $98.8 \%(\mathrm{CV}=0.7 \%)$ for the dilution factor 2 and $98.4 \%$ $(\mathrm{CV}=0.9 \%)$ for the dilution factor 5 .

\section{8. Sample Preparation Recovery}

Extraction recovery of candesartan as well as internal standard was determined at four candesartan QC concentrations $(3,15,75,280 \mathrm{ng} / \mathrm{mL})$ and one concentration $(100 \mathrm{ng} / \mathrm{mL})$ of internal standard. The recovery of candesartan sample preparation was evaluated by comparing mean candesartan responses of eight processed sources of quality control samples with mean candesartan responses of eight standard solutions of QC samples which were spiked into blank extracts. The CV at each level was less or equal to $8.8 \%$, with extraction recovery from 63.1 to $74.6 \%$.

\section{9. Hemolysis Effect}

Eight replicates of low $(3 \mathrm{ng} / \mathrm{mL})$ and high $(280$ $\mathrm{ng} / \mathrm{mL}$ ) QC samples were prepared with hemolyzed human plasma, processed and analyzed in a single run. Concentrations were calculated to evaluate the hemolysis effect with precision and accuracy. An acceptable accuracy (range $94.7 \%$ to $100.1 \%$ ) and precision (range 
$1.7 \%$ to $1.8 \%$ ) of candesartan concentration was observed. Thus, it was demonstrated that hemolysis did not affect the determination of candesartan in human plasma.

\section{10. Solution Stability}

Stability of candesartan as well as internal standard was checked by analyzing eight replicates of stability solutions at different storage conditions in comparison with eight replicates of freshly prepared solutions. Solution stability was checked at two candesartan concentration levels (3 ng/mL and $280 \mathrm{ng} / \mathrm{mL})$ and one concentration level of internal standard $(100 \mathrm{ng} / \mathrm{mL})$.

The following storage conditions were tested:

- long-term stock solution stability of candesartan and internal standard for 35 days at $+5^{\circ} \mathrm{C}$,

- long-term working solution stability of candesartan and internal standard for 35 days at $+5^{\circ} \mathrm{C}$,

- short-term working solution stability of candesartan and internal standard at $+23{ }^{\circ} \mathrm{C}$ for $24 \mathrm{~h}$

The prepared solutions for long-term stability were stored for 35 days at a temperature of $+5{ }^{\circ} \mathrm{C}$ and analyzed only after this period by comparing the peak areas with the freshly prepared solutions. The results are listed in Table 4.

\section{11. Stability in Plasma}

The stability of candesartan at different storage conditions in plasma and extracts prepared for the LCMS/MS analysis was tested at two different concentration levels ( $3 \mathrm{ng} / \mathrm{mL}$ and $280 \mathrm{ng} / \mathrm{mL}$ ). Samples were stored under different conditions. The mean concentration at each level was compared with the mean of the freshly prepared concentrations.

Stability conditions tested in plasma and extracts (abbreviations are given in the brackets):

- after one freeze-thaw cycle, $24 \mathrm{~h}$ at $+5{ }^{\circ} \mathrm{C}$ and $4 \mathrm{~h}$ at room temperature [1x F-T],

- after three freeze-thaw cycles at $-20{ }^{\circ} \mathrm{C}[3 \mathrm{x} \mathrm{F-T}]$,

- after seven days at $-80{ }^{\circ} \mathrm{C}$ and two days at $-20{ }^{\circ} \mathrm{C}$ $\left[-80{ }^{\circ} \mathrm{C}\right]$,
- after freezing at $-20{ }^{\circ} \mathrm{C}$ for 195 days - long-term stability [195 days],

$-120 \mathrm{~h}$ in autosampler at $+5{ }^{\circ} \mathrm{C}-$ stability of extracted sample [120 h AS].

The results are listed in Table 5.

Table 5: Stability of candesartan in human plasma.

\begin{tabular}{cccc}
\hline Stability in plasma & Conc. $(\mathbf{n g} / \mathbf{m L})$ & CV $(\%)$ & Accuracy $(\%)$ \\
\hline \multirow{2}{*}{1 x F-T } & 3 & 3.3 & 100.0 \\
& 280 & 3.3 & 99.2 \\
3 x F-T & 3 & 2.8 & 102.7 \\
& 280 & 1.2 & 100.3 \\
$-80{ }^{\circ} \mathrm{C}$ & 3 & 6.6 & 99.1 \\
& 280 & 2.3 & 99.9 \\
195 days & 3 & 3.2 & 99.4 \\
& 280 & 2.3 & 96.5 \\
120 h AS & 3 & 1.7 & 102.7 \\
& 280 & 0.7 & 101.9 \\
\hline
\end{tabular}

\section{12. Carry-over Test Performance}

Determination of the carry-over at the sample preparation step was done by extracting the sample of blank human plasma immediately after the extraction of sample at the highest concentration level of the calibration curve $(400 \mathrm{ng} / \mathrm{mL})$ in eight replicates. For all carry-over blank samples the peak area at the retention time of candesartan was below $30 \%$ relative to the peak area of the lowest calibration sample at $1 \mathrm{ng} / \mathrm{mL}$ of candesartan. The peak area at the retention time of internal standard in all carryover blank samples was below 5\% relative to the peak area of internal standard obtained for the lowest calibration sample.

In order to verify that there is no carry-over in the instrument LC-MS/MS, the mobile phase was injected immediately after eight consequent injections of extract of the highest concentration of the calibration curve. No significant interference was observed at the retention time of candesartan or internal standard in the blank samples. Carry-over in the method is consistent with the acceptance criteria given in Table 1 .

Table 4: Stability of candesartan and internal standard in solutions.

\begin{tabular}{|c|c|c|c|}
\hline Solution stability & Conc. $(\mathrm{ng} / \mathrm{mL})$ & CV (\%) & Accuracy (\%) \\
\hline \multirow{2}{*}{ Long-term stock solution candesartan $\left(35\right.$ days, $\left.+5^{\circ} \mathrm{C}\right)$} & 3 & 3.4 & 103.1 \\
\hline & 280 & 0.6 & 104.6 \\
\hline \multirow{2}{*}{ Long-term working solution candesartan $\left(35\right.$ days, $+5{ }^{\circ} \mathrm{C}$ ) } & 3 & 2.7 & 1077.9 \\
\hline & 280 & 2.4 & 100.6 \\
\hline \multirow{2}{*}{ Short-term working solution candesartan ( 24 hours, $+23^{\circ} \mathrm{C}$ ) } & 3 & 4.4 & 99.3 \\
\hline & 280 & 3.3 & 100.5 \\
\hline Long-term stock solution internal standard $\left(35\right.$ days, $\left.+5^{\circ} \mathrm{C}\right)$ & 100 & 3.0 & 102.3 \\
\hline Long-term working solution internal standard ( 35 days, $+5^{\circ} \mathrm{C}$ ) & 100 & 3.5 & 100.3 \\
\hline Short-term working solution internal standard ( 24 hours, $\left.+23{ }^{\circ} \mathrm{C}\right)$ & 100 & 3.0 & 95.8 \\
\hline
\end{tabular}




\section{13. Application of the Method to Pharmacokinetic Study}

The validated method has been successfully used in the bioavailability studies of various candesartan dosage forms, to analyze more than 2500 samples. Tables 6 and 7 show the results for linearity, repeatability and accuracy obtained during one of the studies with the $32 \mathrm{mg}$ candesartan formulation, where the narrowed calibration range 4-400 ng/mL was used. method also shows very good precision and accuracy over a longer period of time. A representative pharmacokinetic profile is shown in Figure 3.

\section{Conclusions}

The article presents validation of LC-MS/MS method for the determination of candesartan in human plasma

Table 6: Linearity of candesartan determination within the study.

\begin{tabular}{lcccrrrrr}
\hline Nominal conc. $(\mathbf{n g} / \mathbf{m L})$ & $\mathbf{4}$ & $\mathbf{1 0}$ & $\mathbf{2 5}$ & $\mathbf{5 0}$ & $\mathbf{1 0 0}$ & $\mathbf{2 0 0}$ & $\mathbf{3 0 0}$ & $\mathbf{4 0 0}$ \\
& \multicolumn{7}{c}{ Calculated concentration $(\mathbf{n g} / \mathbf{m L})$} \\
\hline Mean $(\mathrm{N}=24)$ & 4.02 & 10.07 & 24.50 & 50.20 & 101.1 & 197.3 & 302.8 & 399.1 \\
CV $(\%)$ & $\mathbf{4 . 9}$ & $\mathbf{2 . 7}$ & $\mathbf{2 . 1}$ & $\mathbf{3 . 5}$ & $\mathbf{2 . 2}$ & $\mathbf{1 . 6}$ & $\mathbf{1 . 9}$ & $\mathbf{1 . 5}$ \\
Accuracy $(\%)$ & $\mathbf{1 0 0 . 5}$ & $\mathbf{1 0 0 . 7}$ & $\mathbf{9 8 . 0}$ & $\mathbf{1 0 0 . 4}$ & $\mathbf{1 0 1 . 1}$ & $\mathbf{9 8 . 6}$ & $\mathbf{1 0 0 . 9}$ & $\mathbf{9 9 . 8}$ \\
\hline
\end{tabular}

Table 7: Precision and accuracy of candesartan determination within the study.

\begin{tabular}{lccr}
\hline $\begin{array}{l}\text { Nominal conc. } \\
\text { (ng/mL) }\end{array}$ & \multicolumn{12}{c}{$\mathbf{6 0}$} & $\begin{array}{r}\mathbf{2 5 0} \\
\text { Calculated concentration } \\
(\mathbf{n g} / \mathbf{m L})\end{array}$ \\
\hline Mean $(\mathrm{N}=96)$ & 12.21 & 61.23 & 248.0 \\
CV $(\%)$ & $\mathbf{2 . 9}$ & $\mathbf{2 . 1}$ & $\mathbf{1 . 8}$ \\
Accuracy $(\%)$ & $\mathbf{1 0 1 . 8}$ & $\mathbf{1 0 2 . 1}$ & $\mathbf{9 9 . 2}$ \\
\hline
\end{tabular}

The developed and validated method has been proved to be effective in practice as it can be used for analyzing a large number of samples in a short time. The

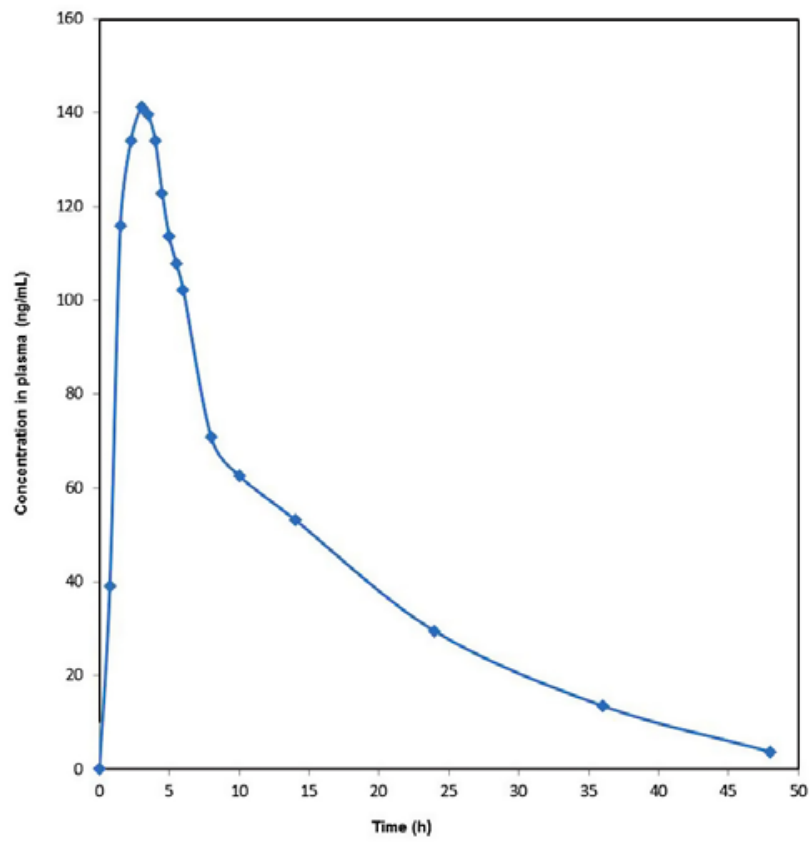

Figure 3: Pharmacokinetic profile of candesartan after administration of the $32 \mathrm{mg}$ candesartan formulation. in accordance with the Viswanathan et al. ${ }^{10}$ requirements and OECD Principles of Good Laboratory Practice ${ }^{11}$ and its application in pharmacokinetic studies. An advantage of the method was the use of the deuterated candesartan (candesartan- $\mathrm{d}_{4}$ ) as the internal standard, which is very similar to candesartan in its physical-chemical properties. With the selected internal standard, most of the unwanted matrix effects were compensated in sample preparation and detection.

Solid-phase extraction was chosen for sample cleanup due to the advantages of selectivity by a clean extract, decreased use of solvents and high efficiency. Besides, there is no need for solvent evaporation. This step was done by extraction on modular Zymark system which enables fast method development with a small number of samples and efficient optimization of each stage of the extraction.

Additional advantage of the method is the fact that due to the small injection volume $(10 \mu \mathrm{L})$ and clean extract free of interferences, a number of extracts can be analysed on a single chromatographic column.

The validation results indicate that the presented method is sensitive, specific, accurate and reproducible within the wide candesartan concentration range ( 1 to 400 $\mathrm{ng} / \mathrm{mL}$ ). Therefore, it is suitable for the routine analysis of large numbers of samples in pharmacokinetic studies of different candesartan dosages.

\section{References}

1. Takeda Products Ireland Ltd, Blopress tablets, http://www.medicines.ie/medicine/14470/SPC/Blopress +tablets/, (assessed: May 25, 2015)

2. H. G. Brittain, Profiles of drug substances, excipients and related methodology, Volume 37, Elsevier publications: Boston, USA, 2012. 
3. J. Nie, M. Zhang, Y. Fan, Y. Wen, B.R. Xiang, Y. Q. Feng, J. Chromatogr. B 2005, 828, 62-69.

http://dx.doi.org/10.1016/j.jchromb.2005.09.015

4. D. V. Bharathi, K. K. Hotha, P. K. Chatki, V. Satyanarayana, V. Venkateswarlu, Bioanal. 2012, 4, 1195-1204. http://dx.doi.org/10.4155/bio.12.83

5. B. Singh, R. S. Lokhandae, A. Dwivedi, S. Sharma, N. Dubey, J. Pharm. Anal. 2014, 4, 144-152. http://dx.doi.org/10.1016/j.jpha.2013.05.003

6. M. Levi, G. Wuerzner, E. Ezan, A. Pruvost, J. Chromatogr. B 2009, 877, 919-926.

http://dx.doi.org/10.1016/j.jchromb.2009.02.030

7. V. K. Karra, N. R. Pilli, J. K. Inamadugu, J. V. L. N. S. Rao, J. Pharm. Anal. 2012, 2, 167-173.

http://dx.doi.org/10.1016/j.jpha.2012.01.002
8. H. Lou, Z. Ruan, B. Jiang, J. Liq. Chromatogr. Related Technol. 2012, 35, 1027-1037.

http://dx.doi.org/10.1080/10826076.2011.615092

9. S. T. Prajapati, P. K. Patel, M. Patel, V. B. Chauhan, C. N. Patel, Pharm. Methods 2011, 2, 130-134. http://dx.doi.org/10.4103/2229-4708.84460

10. C. T. Viswanathan, S. Bansal, B. Booth, A. J. De Stefano, M. J. Rose, J. Sailstad, V. P. Shah, J. P. Skelly, P. G. Swann, R. Weiner, AAPS Journal 2007, 9, 30-42. http://dx.doi.org/10.1208/aapsj0901004

11. OECD Council, OECD Principles of Good Laboratory Practice, OECD Council, 1997.

12. T. Vnučec Popov, L. Cvitkovič Maričič, H. Prosen, D. Brodnjak Vončina, Acta Chim. Slov. 2013, 60, 144-150.

\section{Povzetek}

Za določevanje kandesartana $\mathrm{v}$ humani plazmi smo razvili in validirali LC-MS/MS metodo in dokazali, da je selektivna, občutljiva in ponovljiva. Za pripravo plazemskih vzorcev smo uporabili ekstrakcijo na trdni fazi. Za kromatografsko separacijo smo uporabili kolono Gemini C18 z mobilno fazo acetonitril - $5 \mathrm{mM}$ amonijev formiat $(90: 10, v / v)$ pri pretoku $0,3 \mathrm{ml} / \mathrm{min}$. Za detekcijo smo uporabili tandemsko masno spektrometrijo $\mathrm{v}$ SRM načinu $\mathrm{z}$ uporabo pozitivne ionizacije $\mathrm{z}$ elektro razprševanjem. Uporabljeni so bili masni prehodi: za kandesartan $m / z$ 443,1 > 263,1 in za kandesartan-d4 kot interni standard 445,5 > 267,1. Po končanem razvoju smo metodo validirali v koncentracijskem območju $1-400 \mathrm{ng} / \mathrm{ml} \mathrm{v}$ vzorcih humane plazme. Spodnja meja kvantitativne določitve je bila $1 \mathrm{ng} / \mathrm{ml}$. Razvita in validirana metoda se je izkazala za zelo učinkovito pri farmakokinetičnih študijah. 